\title{
A statistic approach to electronic moulding versus traditional plaster moulding
}

\author{
JC De Mauroy ${ }^{1 *}$, F Barral $^{2}$, C Lecante ${ }^{2}$ \\ From 8th International Conference on Conservative Management of Spinal Deformities and SOSORT 2011 \\ Annual Meeting \\ Barcelona, Spain. 19-21 May 2011
}

\section{Background}

Electronic moulding tends to gradually replace the plaster moulding. Is it as effective?

\section{Materials and methods}

The angular correction of 166 plaster moulding scoliosis was compared with the correction of 117 electronic moulding scoliosis. Both mouldings were made by the same physician. The electronic moulding has been produced using the full 3D system ORTEN. The curves have been grouped into thoracic $(n=127)$, thoracolumbar $(n=65)$ and lumbar $(\mathrm{n}=206)$.

\section{Results}

1) The average initial angle is: $28,19(+-9,21)$ for thoracic, $28,11(+-9,34)$ for thoraco-lumbar and 25,86 $(+-7,04)$ for lumbar curves.

2) The angular reducibility is $54 \%$ in braces for the thoracic curvatures, $69 \%$ for the thoraco-lumbar curvatures and of $73 \%$ for the lumbar curvatures, which corresponds to the usual results of the Lyon management. If we select curves of $30^{\circ}$ and more the reducibility is respectively: $48,5 \%$ for thoracic, $67 \%$ for thoraco-lumbar and lumbar curves.

3) The reducibility in brace is better for the group of the electronic moulding than for the group in plaster cast. For all cases, the improvement of reducibility is $3,63^{\circ}$ for thoracic, 3,02 for thoraco-lumbar and $2,14^{\circ}$ for lumbar curves. This improvement is better if we select the initial curves of $30^{\circ}$ and more: respectively $5,44^{\circ}$ for thoracic, $4,75^{\circ}$ for thoraco-lumbar and $3,89^{\circ}$ for lumbar curves. This difference is however not statistically significant.

${ }^{1}$ Clinique du Parc, Lyon, France

Full list of author information is available at the end of the article

\section{Conclusions}

Such results are in favour of the electronic moulding, which remains however delicate and require a precise position of the patient during the surface topography and well trained orthotic technicians.

\section{Author details \\ ${ }^{1}$ Clinique du Parc, Lyon, France. ${ }^{2}$ Groupe Lecante, Lyon, France.}

Published: 27 January 2012

doi:10.1186/1748-7161-7-S1-042

Cite this article as: De Mauroy et al:: A statistic approach to electronic moulding versus traditional plaster moulding. Scoliosis 2012 7(Suppl 1): O42.
Submit your next manuscript to BioMed Central and take full advantage of:

- Convenient online submission

- Thorough peer review

- No space constraints or color figure charges

- Immediate publication on acceptance

- Inclusion in PubMed, CAS, Scopus and Google Scholar

- Research which is freely available for redistribution
() Biomed Central

\section{() Biomed Central}

